\title{
Parthenolide suppresses hypoxia-inducible factor-1 $\alpha$ signaling and hypoxia induced epithelial-mesenchymal transition in colorectal cancer
}

\author{
SE LIM KIM ${ }^{1,2}$, YOUNG RAN PARK ${ }^{1,2}$, SOO TEIK LEE ${ }^{1,2}$ and SANG-WOOK KIM ${ }^{1,2}$ \\ ${ }^{1}$ Department of Internal Medicine, Research Institute of Clinical Medicine of Chonbuk National University, \\ ${ }^{2}$ Biomedical Research Institute of Chonbuk National University Hospital, \\ Chonbuk National University Medical School, Jeonju, Republic of Korea
}

Received July 3, 2017; Accepted September 29, 2017

DOI: $10.3892 /$ ijo.2017.4166

\begin{abstract}
Activation of hypoxia-inducible factor $1 \alpha$ (HIF-1 $\alpha)$ is frequently observed in solid tumors and it has been associated with various pathophysiological processes, including epithelial-mesenchymal transition (EMT). Previously, we reported that parthenolide (PT), an inhibitor of nuclear factor- $\mathrm{\kappa B}(\mathrm{NF}-\mathrm{\kappa B})$, is a promising anticancer agent because it promotes apoptosis of human colorectal cancer (CRC). Here, we investigated a new molecular mechanism by which PT acts on HIF- $1 \alpha$ and hypoxia contributing to EMT by NF- $\mathrm{KB}$ inhibition. Cell viability, DNA binding activity, vascular cell tube formation and cell motility were studied after treatment of PT in hypoxic or normoxic condition. Moreover, effects of PT on hypoxia signaling and hypoxia-induced EMT signaling were investigated. We also examined the inhibitory effect of PT on CRC progression in xenografts. We demonstrated that PT markedly inhibits hypoxia dependent HIF-1 $\alpha$ activity and angiogenesis by preventing NF- $\kappa \mathrm{B}$ activation. We also report that PT decreases the level of proteins associated with glucose metabolism, angiogenesis, development and survival that are regulated by HIF-1 $\alpha$. Furthermore, we verified that PT protects the morphological change from epithelial to mesenchymal state, inhibits matrix metalloproteinase (MMP) enzyme activity and decreases cell motility involved in the regulation of the hypoxia-induced EMT markers. In addition, PT inhibits growth in CRC xenograft models and regulates NF- $\kappa B, H I F-1 \alpha$ and EMT specific marker in tissue specimens. Our data demonstrated that PT can inhibit HIF-1 $\alpha$ signaling and hypoxia-induced EMT, suggesting a novel molecular mechanism for HIF-1 $\alpha$ mediated cancer progression and metastasis.
\end{abstract}

Correspondence to: Dr Sang-Wook Kim, Department of Internal Medicine, Chonbuk National University Hospital, 20 Geonji-ro, Deokjin-gu, Jeonju 561-712, Republic of Korea

E-mail: clickm@jbnu.ac.kr

Key words: parthenolide, hypoxia-inducible factor $1 \alpha, \mathrm{NF}-\kappa \mathrm{B}$, angiogenesis, epithelial-mesenchymal transition

\section{Introduction}

The hypoxic environment is a phenomenon specific to cancer pathophysiology, in which quickly growing solid tumors result in poor development of angiogenic vessels, thus leading to an insufficient supply of oxygen $(1,2)$. Hypoxic responses are highly controlled by hypoxia-inducible factors (HIFs), which are transcription factors with critical roles in the development and progression of various tumors, including colorectal cancer (CRC) (3-5). The prototypic member of the HIF family is HIF-1, which is a heterodimer consisting of an oxygen concentration-dependent $\alpha$ subunit and a constitutively expressed $\beta$ subunit $(6,7)$. In normal oxygen concentration, HIF-1 $\alpha$ is rapidly degraded by prolyl hydroxylases (PHDs) at proline residues within the oxygen-dependent degradation domain. This degradation mediates interaction with PHDs and the von Hippel-Lindau (pVHL) tumor suppressor protein, eventually leading to HIF-1 $\alpha$ degradation through a VHL-dependent ubiquitin-proteasome pathway (8). On the contrary, under hypoxic condition, the $\mathrm{O}_{2}$-dependent PHDs are inhibited, thereby inhibiting the interaction between HIF-1 $\alpha$ and pVHL. Therefore, HIF-1 $\alpha$ ubiquitination/degradation is suppressed, resulting in increased protein expression of HIF-1 $\alpha$ (9).

One of the mechanisms by which HIF-1 promotes cancer progression is by inducing the epithelial-mesenchymal transition (EMT). EMT is a phenotypic change in which epithelial cells transform to spindle-like motile cells that express mesenchymal markers $(10,11)$. Epithelial cells lose their cell-cell adhesion properties and cell polarity and acquire invasive properties, which permit access to the vessel (12). Through this process, tumor cells experience migration and invasion, leading to cancer progression and metastasis (13). Among the HIFs, HIF-1 $\alpha$ in particular has been studied to promote EMT in several types of cancers by modulating EMT-associated genes, including TWIST, snail, and slug (14-16). Since hypoxia-induced EMT plays a key role in metastasis, EMT is believed to be a promising target for developing new and effective anticancer therapies.

Parthenolide (PT) can be isolated from extracts of Mexican Indian medicinal plants that show anti-inflammatory 
properties. Moreover, PT is currently used clinically to treat migraines $(17,18)$. The biological activities of PT are mediated by suppression of nuclear factor- $\kappa \mathrm{B}(\mathrm{NF}-\kappa \mathrm{B})$ signaling, which entails inhibition of $\mathrm{I} \kappa \mathrm{B}$ kinase, alteration of NF- $\kappa \mathrm{B}$ binding activity and modification of the p65 protein (17,19-21). We previously used a colitis-associated colorectal cancer (CAC) model to demonstrate that PT inhibits NF- $\mathrm{BB}$ activation, ultimately preventing $\mathrm{CAC}$ development and carcinogenesis (22).

$\mathrm{NF}-\kappa \mathrm{B}$ is a central molecule involved in inflammation that regulates the expression of various target genes that promote cell proliferation, modulate immune and inflammatory responses, and play a role in the pathogenesis of various diseases, including cancer $(23,24)$. Both HIF- $1 \alpha$ and NF- $\kappa \mathrm{B}$ are involved in cancer progression and have been implicated in the tumor responses to hypoxia (25). Moreover, positive correlations between HIF-1 $\alpha$ and NF- $\mathrm{NB}$ have been shown in various cancer cells including lung cancer cells, CRC cells, osteosarcoma and gastric cancer cells (26-29). However, the mechanism of HIF- $1 \alpha$ and NF- $\kappa \mathrm{B}$ activation under hypoxia still remains unclear. Interestingly, several studies have reported that activation of $N F-\kappa B$ is closely involved in the progression of EMT by regulating EMT-specific genes in cancer cells (30-32). Therefore, we hypothesized that NF- $\kappa \mathrm{B}$ inhibition may regulate both HIF-1 $\alpha$ signaling and hypoxia-induced EMT progression.

We designed this study to test our hypothesis that PT significantly inhibits hypoxic response and hypoxia mediated EMT through blockade of $\mathrm{NF}-\kappa \mathrm{B}$ activation, thus resulting in suppression of tumor growth, angiogenesis and invasion in CRC. We tested this hypothesis using both in vitro and in vivo models.

\section{Materials and methods}

Chemicals and reagenst. Parthenolide was from Calbiochem (San Diego, CA, USA) and it was dissolved in dimethylsulfoxide (DMSO; Sigma, St. Louis, MO, USA). Growth factor-reduced Matrigel was purchased from BD Biosciences (San Diego, CA, USA). Anti-HIF-1 $\alpha$, anti-VHL, anti-p65, anti-VEGF, anti-hexokinase II, anti-GLUT1, anti-COX2, anti-PI3K, anti-TWIST, anti-Lamin B and anti-CA IX were purchased from Santa Cruz Biotechnology, Inc. (Santa Cruz, CA, USA). Anti-AKT, anti-phospho-AKT, anti-ERK1/2, anti-phospho-ERK1/2, anti-MMP9, anti-E-cadherin, anti- $\beta$-catenin and anti-vimentin were from Cell Signaling Technology (Danvers, MA, USA). Anti-MMP2, anti-Slug and anti-Snail were from Abcam (Cambridge, UK). Anti-actin was purchased from Sigma-Aldrich (St. Louis, MO, USA).

Cell culture, treatments and observation of morphological changes. HT-29, DLD-1 and HCT116 cells (American Type Culture Collection ATCC, Rockville, MD, USA) were employed as representative human CRC cells. The cells were cultured in RPMI-1640 medium supplemented with 10\% FBS, $100 \mathrm{U}$ penicillin, and $100 \mathrm{U}$ streptomycin. Human umbilical vein endothelium cells (HUVECs) were also purchased from ATCC and cultured in endothelial cell growth medium (EGM ${ }^{\circledR}-2$ MV Bullet kit) (Lonza, Walkersville, MD, USA) containing $2 \%$ fetal bovine serum (FBS). HUVECs were used at 2-5 passages. Normoxia (general air condition, $21 \% \mathrm{O}_{2}$ ) and hypoxia $\left(1 \% \mathrm{O}_{2}, 5 \% \mathrm{CO}_{2}\right.$ and $\left.94 \% \mathrm{~N}_{2}\right)$ incubation was performed after PT treatment for indicated times at $37^{\circ} \mathrm{C}$.

The morphological alterations in the HT-29 cells were observed using an inverted microscope. Images were captured using an inverted microscope (Olympus IX71, USA).

Quantification of cell viability. The number of living cells was determined by staining of the cells with the vital dye trypan blue. HUVECs and CRC cells were plated at a density of $1 \times 10^{4}$ cells per well in 24-well plates. Cells were treated with PT in normoxic or hypoxic condition for $24 \mathrm{~h}$. After the medium was removed, cells were harvested with trypsin-EDTA and re-suspended in fresh medium. The cells in medium was diluted with trypan blue, and counted employing a hematocytometer.

Reverse transcription-PCR. Total RNA was isolated from cultured cells using TRIzol (Invitrogen, Eugene, OR, USA) and cDNA was synthesized with SuperScript II reversetranscriptase (Invitrogen) according to the manufacturer's protocol. The expression level of GAPDH gene was used as a loading control. The following primer sequences were used: HIF-1 $\alpha$, 5'-GCTGGCCCCAGCCGCTGGAG-3' (forward) and 5'-GAGTGCAGGGTCAGCACTAC-3' (reverse), generating 214-bp product; VEGF, 5'-ACCCATGGCAGAAGGAG GAG-3' (forward) and 5'-ACGCGAGTCTGTGTTTTTGC-3' (reverse), generating 487-bp product. After initial denaturation at $94^{\circ} \mathrm{C}$ for $5 \mathrm{~min}, \mathrm{PCR}$ was performed for 30 cycles (30 sec at $94^{\circ} \mathrm{C}, 1 \mathrm{~min}$ at annealing temperature and $30 \mathrm{sec}$ at $72^{\circ} \mathrm{C}$ ) using Taq polymerase. Reaction products $(10 \mu \mathrm{l})$ were separated on 1.5-2\% agarose gel, and stained with Redsafe ${ }^{\mathrm{TM}}$ (Intron, Daejeon, Korea). DNA band intensity was analyzed by densitometry using NaBI imager and SET ROI software (Neogene Science, Suwon, Korea).

Cytoplasmic and nuclear extract preparation. Cells were harvested and resolved in a 400- $\mu$ l cytosolic lysis buffer [10 mM HEPES (pH 7.9), 10 mM KCl, 0.1 mM EDTA, 1 mM dithiotreitol (DTT) and $1 \mathrm{mM}$ phenylmethylsulphonylfluoride (PMSF) and protease inhibitor cocktail]. After reaction for $10 \mathrm{~min}$ on ice, $10 \% \mathrm{NP}-40$ was added and strongly vortexed for $1 \mathrm{~min}$. After centrifugation at 3,000 rpm for $1 \mathrm{~min}$, the supernatants were used as cytoplasmic extracts. The resulting pellets were resolved in $100 \mu \mathrm{l}$ of nuclear lysis buffer [ $20 \mathrm{mM}$ HEPES (pH 7.9), $420 \mathrm{mM} \mathrm{NaCl}, 1.5 \mathrm{mM} \mathrm{MgCl}_{2}, 0.2 \mathrm{mM}$ EDTA, $0.5 \mathrm{mM}$ dithiotreitol, $0.5 \mathrm{mM}$ phenylmethylsulphonylfluoride and protease inhibitor cocktail] for $30 \mathrm{~min}$ on ice. After centrifugation at $14,000 \mathrm{rpm}$ for $15 \mathrm{~min}$, the supernatants were used as nuclear extracts.

Electrophoretic mobility shift assay (EMSA). We performed EMSA for determination of NF- $\mathrm{B}$ activation using the biotin-labeled NF- $\kappa$ B probe: 5'-AGTTGAGGGGACTTTC CCAGGC-3'. Biotin-labeled NF- $\kappa$ B probe $(2 \mu \mathrm{g}$ of nuclear extracts) and binding buffer including poly(dIdC) were incubated at $15^{\circ} \mathrm{C}$ for $30 \mathrm{~min}$ in a final volume of $10 \mu \mathrm{l}$. Specific binding was controlled by competition with a cold NF- $\kappa \mathrm{B}$ probe. The reaction mixture was separated by electrophoresis on a non-denaturing polyacrylamide gel. After electrophoresis at $120 \mathrm{~V}$ for $50 \mathrm{~min}$, oligonucleotides were transferred to a 
Biodyne B positively charged nylon membrane (Pall, Basel, Switzerland) at $300 \mathrm{~mA}$ for $30 \mathrm{~min}$ by the wet transfer method. The membrane was fixed for $1 \mathrm{~h}$ at $80^{\circ} \mathrm{C}$, then blocked by blocking buffer for $1 \mathrm{~h}$ then streptavidin-HRP was added in blocking buffer. After washing, signals were detected by chemiluminescent imaging according to the manufacturer's protocol (EMSA Gel Shift kit; Panomics, Redwood City, CA, USA).

Western blotting and immunoprecipitation analysis. The protein concentration in cell lysates was determined using a Protein Quantification kit (Bio-Rad, TX, USA). Fifty micrograms of protein or $30 \mu \mathrm{g}$ of nuclear extract protein was loaded onto an SDS-polyacrylamide gel. After transferring and blocking, the polyvinylidene difluoride (PVDF) membrane was probed with various antibodies. The binding of antibody was detected using enhanced ECL prime (GE Healthcare, NJ, USA), captured and analyzed by the Las-3000 luminescent Image Analyzer (Fuji Film, Tokyo, Japan).

For immunoprecipitation, $100 \mu \mathrm{g}$ of cell extracts was incubated overnight with $4 \mu \mathrm{g}$ of anti-HIF-1 $\alpha$ or anti-mouse-IgG antibody. The resulting immunocomplex was precipitated by adding $40 \mu \mathrm{l}$ of protein A-agarose slurry at $4^{\circ} \mathrm{C}$ for $18 \mathrm{~h}$. The complex was washed with lysis buffer, separated by SDS-PAGE and transferred to a PVDF membrane. The membrane was probed with an anti-VHL antibody and visualized using Las-3000 luminescent Image Analyzer.

Tubeformation assay with HUVECs on Matrigel. Two hundred microliter of Matrigel was added to a 24-well plate and solidified for $30 \mathrm{~min}$ at $37^{\circ} \mathrm{C}$. The HUVECs $\left(1 \times 10^{4}\right.$ cells per well) were seeded into each well of the Matrigel-coated plate and then incubated in EGM-2 containing 2\% FBS. After overnight incubation, media were changed to fresh endothelial basal media (EBM-2) in the absence and presence of PT. Capillarylike tube formation was captured by an inverted microscope (Olympus IX71) at x40 magnification. The number of polygons was counted and then tube formation was calculated as a percentage by normalization with control cells under normoxic condition.

In vitro migration and invasion assays. Cell migration was evaluated by the wound-healing assay. HT-29 cells $\left(1 \times 10^{6}\right)$ were seeded in $6-\mathrm{cm}$ culture plates and incubated at $37^{\circ} \mathrm{C}$. The confluent cells were scratched with a $\mathrm{P} 200$ pipette tip to generate a wound $\sim 1 \mathrm{~mm}$ wide. After 48 -h incubation under normoxic or hypoxic condition, images were captured at x10 magnification, and the wound area was determined using an inverted microscope (Olympus IX71). The ability of the cells to close the wound, that is their motility, was evaluated by determining the healed area.

Invasion assays were performed by using a 24-well Transwell chamber (24-wells, $8 \mu \mathrm{m}$ pore size with poly-carbonate membrane; SPL, Pocheon, Korea) with growth factor-reduced Matrigel. Briefly, $1 \times 10^{5}$ cells per well were seeded into upper chamber with serum-free media. The low chamber was filled with $800 \mu \mathrm{l}$ medium containing $10 \%$ FBS as a chemoattractant and allowed to invade for $6 \mathrm{~h}$. Cells remaining above the insert membrane were removed by suction. Then, the cells on the lower side of the membrane were fixed in $3.8 \%$ formaldehyde for 20 min and stained with $0.1 \%$ crystal violet solution. The inserts were washed three times in 1X PBS and air-dried. The numbers of invaded cells in five randomly selected fields were counted using an inverted microscope (Olympus IX71) at x10 magnification and analyzed statistically.

Gelatin zymography. Cells were treated with PT at $37^{\circ} \mathrm{C}$ for $24 \mathrm{~h}$ under normoxic or hypoxic condition, and $100 \mu \mathrm{l}$ of conditioned media were collected. Conditioned media was concentrated by using a speed vacuum concentrator (Thermo Scientific ${ }^{\mathrm{TM}}$, MA, USA). The un-boiled samples were separated by $0.1 \%$ gelatin- $8 \%$ SDS-PAGE electrophoresis. The gels were washed with $2.5 \%$ Triton X-100 at room temperature for $30 \mathrm{~min}$ and then incubated in reaction buffer (10 $\mathrm{mM} \mathrm{CaCl}_{2}, 40 \mathrm{mM}$ Tris- $\mathrm{HCl}$ and $0.01 \% \mathrm{NaN}_{3}, \mathrm{pH} 8.0$ ) at $37^{\circ} \mathrm{C}$ overnight. Coomassie brilliant blue R-250 was then used to stain the gel. Stained gel was located on light box and the image was captured by digital camera.

Nude mouse tumor xenografts study. Six-week-old female athymic nude mice were purchased from Orients Bio (Sungnam, Korea). Animal experiment protocol was reviewed and approved by the Chonbuk National University Animal Care and Use Committee (Approval no: CBU 2012-0035). The tumor was established by injecting $6 \times 10^{6} \mathrm{CRC}$ cells (HT-29) in $50 \mu \mathrm{l}$ of Matrigel subcutaneously into right flanks. Mice were randomized and assigned to control and treatment group and intraperitoneally injected 3 times a week vehicle (DMSO) and $4 \mathrm{mg} / \mathrm{kg}$ PT, respectively. Tumor diameters were measured using a caliper, and the volumes were also calculated using a formula: volume $=\mathrm{X} \times \mathrm{Y} \times \mathrm{Z} \times \pi / 6$. The experiment was terminated on day 27 , and the tumor xenografts were harvested for immunohistochemistry.

Immunohistochemistry. Immunohistochemistry (IHC) was carried out in paraffin-embedded $5-\mu \mathrm{m}$ tissue sections. The sections were immunostained with anti-carbonic anhydrase IX (CA IX), anti-p65, anti-von Willebrand factor (VWF) and anti-vimentin antibody, visualized by appropriate biotin-conjugated secondary antibodies followed by immmunoperoxidase detection with the Vectastain ABC Elite kit (Linaris, Germany) and diamino-benzidine (DAB) substrate (Vector, UK). Five equal-sized fields were randomly chosen. Four fields at X10 magnification were selected and antibody-positive cells were counted.

Statistical analysis. The data are presented as the mean \pm standard deviation (SD) of at least three independent experiments. Representative blots are shown. All the data were entered into the Microsoft Excel 5.0, and Graphpad Prism 5.0 was used to perform the Student's t-tests (for differences between two groups) or the analysis of the variance, where appropriate. P-values of $<0.05$ were considered statistically significant.

\section{Results}

Parthenolide downregulates $H I F-1 \alpha$ protein level in $C R C$ cell lines. Human CRC cell lines, HT-29, DLD-1 and HCT116 cells were treated with various concentrations of PT for $24 \mathrm{~h}$ in normoxic or hypoxic conditions. As shown in Fig. 1A, PT 
A
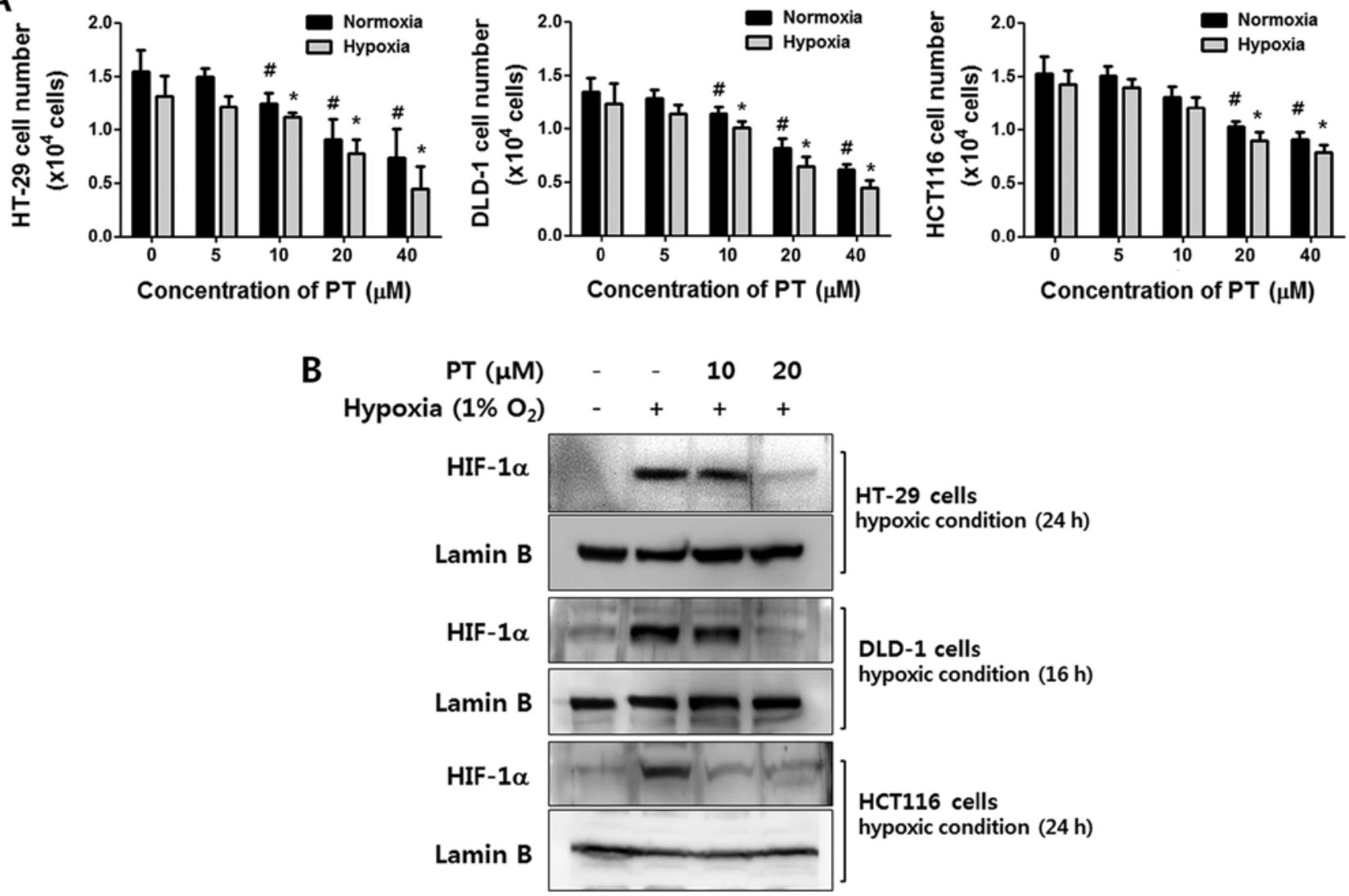

Figure 1. Concentration-dependent effects of PT on human CRC cell viability and HIF-1 $\alpha$ expression. (A) HT-29, DLD-1, and HCT116 cells were treated with various concentrations of PT under normoxic or hypoxic conditions for $24 \mathrm{~h}$. Cell viability was analyzed by cell number counting method. Data represent the mean values \pm SEs of three independent experiments. ${ }^{*} \mathrm{p}<0.05$ versus control in hypoxia, ${ }^{\#} \mathrm{p}<0.05$ versus control in normoxia. (B) Nuclear extracts of CRC cells were prepared and used to quantify the expression levels of HIF-1 $\alpha$. Each cell line was incubated for the indicated time in the hypoxic chamber. Lamin B was used as a nuclear protein loading control.

exhibited a dose-dependent anti-proliferative effect in both oxygen conditions in all CRC cells. Especially, the viability of HT-29 cells was significantly affected in dose-dependent manner (normoxic condition: vehicle $99.20 \pm 3.41 \%, 20 \mu \mathrm{M}$ PT $87.94 \pm 2.77 \%, 40 \mu \mathrm{M}$ PT $49.43 \pm 10.52 \%$, hypoxic condition: vehicle $85.5 .38 \%, 20 \mu \mathrm{M}$ PT $55.89 \pm 8.17 \%, 40 \mu \mathrm{M}$ PT $30.04 \pm 6.75 \%$ ). These results indicate that PT has inhibitory effect on growth regardless of oxygen concentration.

To investigate whether PT regulates HIF-1 $\alpha$ expression in CRC cells under hypoxic conditions, we confirmed the level of HIF-1 $\alpha$ by western blot analysis after treatment with various concentrations of PT. In response to hypoxia, HIF-1 $\alpha$ expression was dramatically increased in all cell lines. Interestingly, under same conditions, PT significantly reduced HIF-1 $\alpha$ expression in a concentration-dependent manner. This downregulation was specific to HIF-1 $\alpha$, as the protein level of lamin $\mathrm{B}$ remained unchanged (Fig. 1B).

$H I F-1 \alpha$ regulation by $P T$ is correlated with $N F-\kappa B$ activation. To investigate whether PT affects the interaction of HIF-1 $\alpha$ and VHL under hypoxia, we performed immunoprecipitation with an anti-HIF-1 $\alpha$ antibody. Interaction VHL and HIF-1 $\alpha$ was decreased under hypoxic conditions, while treatment with $20 \mu \mathrm{M}$ of PT dramatically increased VHL binding to HIF- $1 \alpha$, indicating increased post-translational modification of HIF-1 $\alpha$ (Fig. 2A).
Then, we analyzed the expression of HIF-1 $\alpha$ at both the transcriptional and translational levels for better understanding of the molecular mechanisms by which PT inhibits HIF-1 $\alpha$ signaling in the CRC cells. When cultured in hypoxic condition HIF-1 $\alpha$ protein level was elevated, while HIF- $1 \alpha$ mRNA level was hardly affected. Cells treated with PT and cultured in identical hypoxic conditions exhibited markedly reduced levels of HIF-1 $\alpha$ protein but similar levels of HIF-1 $\alpha$ mRNA, indicating that PT regulates HIF-1 $\alpha$ on the post-transcriptional level (Fig. 2A and B).

Next, we investigated relation between HIF-1 $\alpha$ and hypoxiainduced $\mathrm{NF}-\kappa \mathrm{B}$ activation in $\mathrm{CRC}$ cells using $\mathrm{PT}$ treatment. Since NF- $\kappa \mathrm{B}$ activation results in nuclear translocation of the p65 subunit, we examined protein level of the p65 in nuclear extract by western blotting. As shown in Fig. 2C, the expression level of p65 was dramatically elevated in hypoxic condition without any $\mathrm{NF}-\kappa \mathrm{B}$ stimuli, whereas treatment with PT resulted in a decreased level of nuclear p65, indicating that PT prevents hypoxia-mediated nuclear translocation of p65 (Fig. 2C). Moreover, we observed the effect of PT on the DNA-binding activities of NF- $\mathrm{B}$ in normoxic and hypoxic condition by EMSA. DNA-binding activity of NF- $\kappa \mathrm{B}$ was significantly increased in hypoxia, whereas its DNA-binding activity was almost completely blocked by PT at the maximum concentration tested (Fig. 2D). These results demonstrate that $\mathrm{NF}-\kappa \mathrm{B}$ activation is correlated to HIF-1 $\alpha$ activation in 

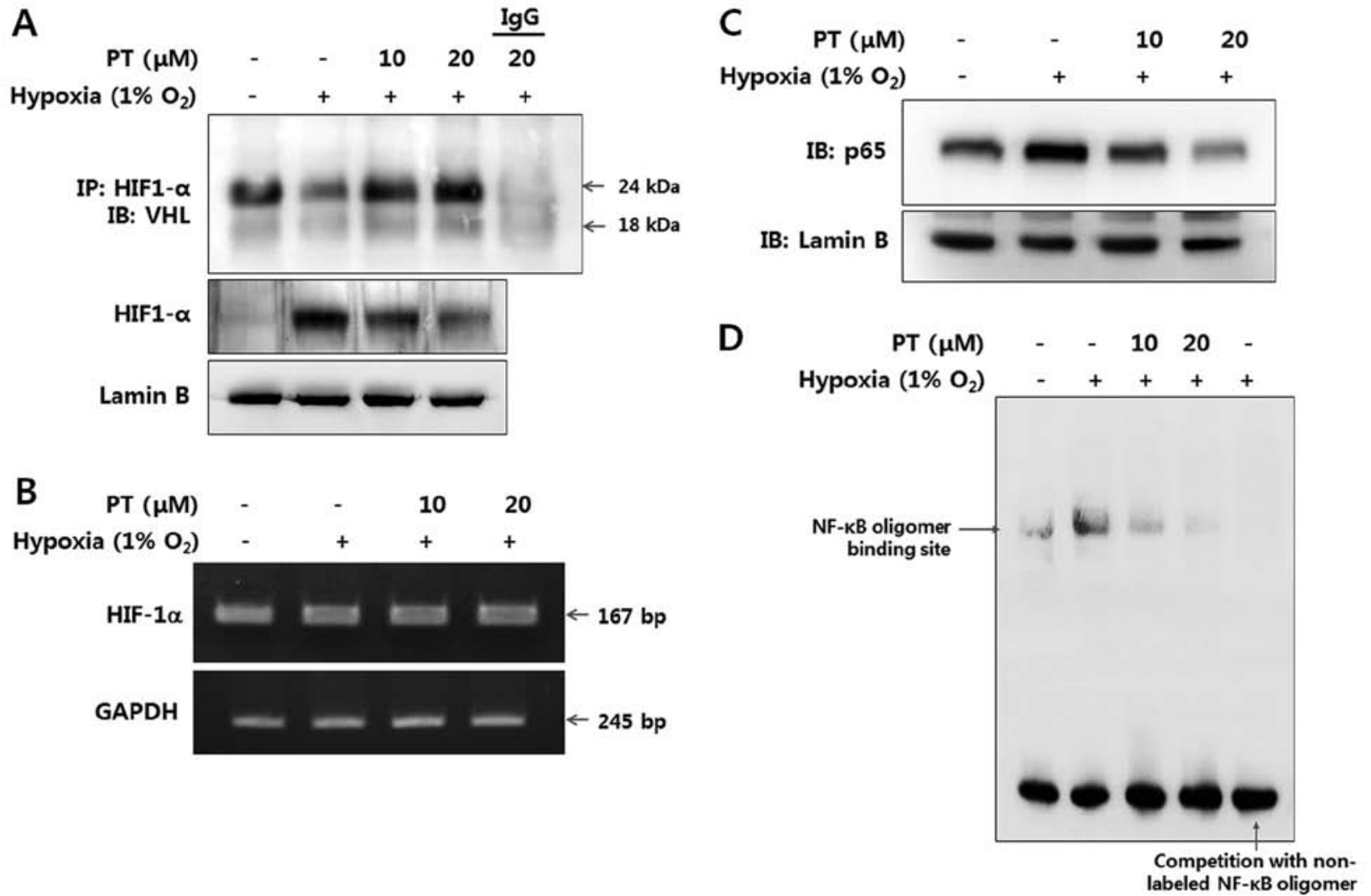

Figure 2. Regulation of the HIF-1 $\alpha$ /VHL interaction and hypoxia-induced NF- $\mathrm{kB}$ activation by PT in HT-29 cells. (A) The level of VHL associated with HIF-1 $\alpha$ was analyzed by immunoprecipitation of HIF-1 $\alpha$ after treatment of cells with various concentrations of PT under normoxic or hypoxic conditions. (B) The mRNA levels of HIF-1 $\alpha$ were determined by RT-PCR analysis and compared to the levels of GAPDH. (C) Nuclear extracts of HT-29 cells were prepared and used to quantify the expression level of NF-kB subunit p65. Lamin B was used as a nuclear protein loading control. (D) Nuclear extracts were prepared and used for electrophoretic mobility shift analysis (EMSA) of NF- $\mathrm{kB}$ DNA binding using an HRP-labeled NF- $\mathrm{kB}$ probe. The cold probe lane contained the 1-h post-stimulation nuclear extract incubated with the HRP-labeled NF-kB probe plus a 10-fold excess of the unlabeled probe. The arrow indicates shifted bands.

CRC cells. Moreover, PT inhibits NF- $\mathrm{B}$ and downregulates hypoxia-induced $\mathrm{NF}-\kappa \mathrm{B}$ activation.

Parthenolide inhibits hypoxia-induced angiogenesis. Vascular endothelial growth factor (VEGF) is a downstream target whose expression is significantly induced by HIF-1 $\alpha$ (33). Thus, we next determined whether PT exerts anti-angiogeneic effect due to its inhibitory effect on HIF-1 $\alpha$ expression. As an in vitro model of angiogenesis, we used HUVECs in culture, and first we evaluated viability of HUVECs in various concentration of PT. Treatment with PT at concentrations $\leq 2.5 \mu \mathrm{M}$ did not affect cell viability. However, at $5 \mu \mathrm{M}$ PT, the viability of the HUVECs was significantly decreased $(81.212 \pm 6.91 \%$, Fig. 3A).

Next, we examined whether PT affects hypoxia-induced HUVEC tube formation on Matrigel. Endothelial cells can spontaneously develop a capillary-like network on Matrigel, which is an important feature of angiogenesis (34). Therefore, we evaluated whether PT suppressed tube formation by counting the polygons (Fig. 3B). HUVECs did not form tubes under normoxic conditions, whereas HUVECs obviously displayed network-like structures after $24 \mathrm{~h}$ in hypoxic condition. However, treatment with PT resulted in significantly reduced tube formation under hypoxic condition. Followed by quantification of tube formation by counting the number of polygons, hypoxic conditions resulted in 10 -fold more tubes that in normoxic conditions; moreover, treatment with $2.5 \mu \mathrm{M}$ PT decreased the polygon number by $\sim 70 \%$ compared with corresponding hypoxic control group. This result indicates that the effect of PT on the tube formation was not due to non-specific cytotoxic effects.

To elucidate the mechanism by which PT exerts its anti-angiogenic activity, we determined the effect of PT on VEGF expression in HUVECs (Fig. 3C). Western blot analysis and reverse-transcriptase PCR revealed that the treatment of the HUVECs with PT markedly decreased the levels of VEGF protein and mRNA in a dose-dependent manner. These results suggest that the anti-angiogenic effect of PT was mediated through the decreased level of HIF-1 $\alpha$ protein.

Parthenolide downregulates HIF-1 $\alpha$ dependent gene products. HIF-1 $\alpha$ is ubiquitously expressed and binds hypoxia response elements (HREs) on several hundred genes, thus facilitating adaptation to hypoxia (35). To investigate whether treatment with PT inhibits the level of target gene products involved in energy metabolism, angiogenesis, survival and development, we analyzed protein level of glucose transporter 1 (GLUT1) and hexokinase II (HXKII), VEGF, phosphoinositide 3-kinase (PI3K) phosphor-AKT, phosphor-ERK1/2 and cyclooxygenase-2 (COX-2) by western blotting. All of target gene products are markedly upregulated in response to hypoxia. We found that treatment with 

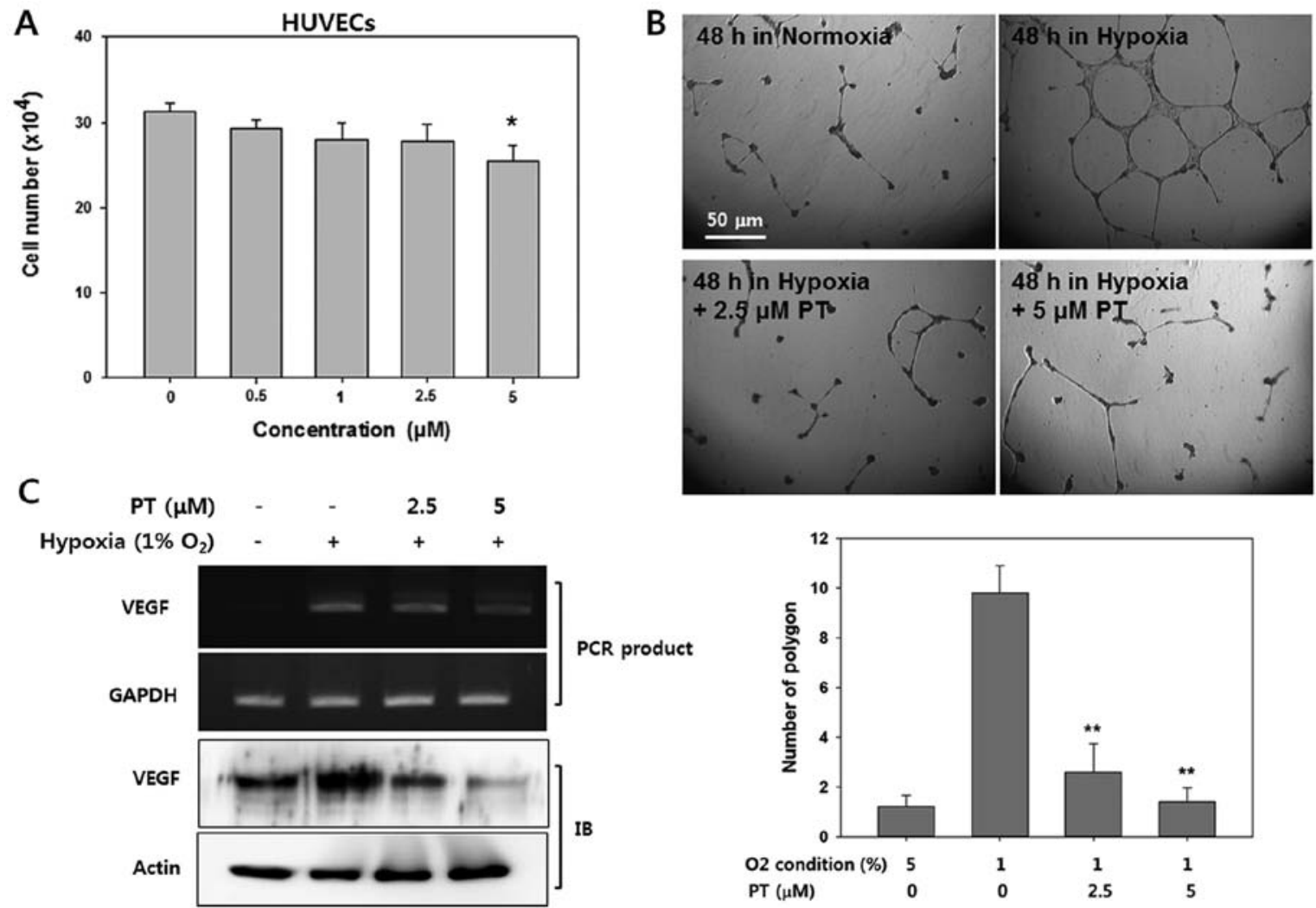

Figure 3. Concentration-dependent suppression of angiogenesis induced by PT treatment. (A) The viability of HUVECs treated with different concentrations of PT was measured by counting viable cells. (B) Culture plates (24-well plates) were coated overnight with Matrigel (200 $\mu 1 /$ well). HUVECs were grown overnight and then exposed to PT under normoxic or hypoxic conditions for $48 \mathrm{~h}$. Photographs of tube formation (x20) were taken. Polygons were counted manually for quantification. Data are presented as means \pm standard errors (SEs). ${ }^{*} \mathrm{p}<0.05$. (C) HUVECs were treated with 2.5 or $5 \mu \mathrm{M}$ PT for $24 \mathrm{~h}$ under hypoxic conditions. The levels of VEGF protein were determined by immunoblotting, whereas the levels of VEGF mRNA were evaluated by RT-PCR analysis. VEGF levels were compared with those of actin and GAPDH, respectively.

PT dramatically inhibited level of these gene products in a concentration-dependent manner (Fig. 4). Thus, PT can decrease glucose metabolism, angiogenesis, survival and development modulated by hypoxia.

Parthenolide prevents hypoxia-induced EMT. Next, we sought to determine if PT modulates hypoxia-induced EMT. Epithelial and mesenchymal cells show distinct phenotypes. Specifically, epithelial cells have apical-basal polarity and form epithelial adherent junctions, whereas mesenchymal cells lack cell polarity and exhibit a spindle-like morphology (36). To assess the effects of PT on hypoxia-induced EMT, we examined the morphological changes under hypoxia. As shown in Fig. 5A, HT-29 cells showed greater isolation and a more spindle-like morphology under hypoxic conditions than under normoxic conditions; these characteristics are typically associated with EMT. However, these hypoxia-induced morphological alteration was inhibited by PT treatment.

To verify that PT blocked hypoxia-induced EMT, cell migration and invasion were evaluated in wound healing and invasion assays using Matrigel coated Transwell chamber. As shown in Fig. 5B, while hypoxia clearly promoted cell migration and invasion, these effects were largely counteracted by PT treatment. Quantification of the wounded area in scratch tests revealed that hypoxia increased the migration distance by $28.13 \pm 2.65 \mu \mathrm{m}$, whereas treatment with $20 \mu \mathrm{M}$ PT significantly reduced by $57.32 \pm 4.29 \mu \mathrm{m}$. Quantification of invading cells showed that $20 \mu \mathrm{M}$ PT significantly inhibited invasion by $\sim 80 \%$ in HT-29 cells (Fig. 5B). These results demonstrate that PT inhibits hypoxia-mediated cell migration and invasion.

MMPs have been identified as a powerful modulator of the promoting invasion and metastasis, moreover HIF-1 $\alpha$ promotes MMPs in hypoxic condition in cancer cells (37). To determine whether PT regulates hypoxia-mediated MMP activity, we analyzed MMP activity in culture supernatants and quantified the protein levels of various MMPs in cell extracts. As shown in Fig. 5C, the levels of hypoxia-mediated MMP2 and MMP9 activity were decreased by PT in a dose-dependent manner. Similarly, PT inhibited hypoxia-mediated induction of MMP2 and MMP9 protein expression (Fig. 5D). Taken together, our results indicate that $\mathrm{PT}$ inhibits hypoxia-induced EMT and reduces the protein levels of MMP2 and MMP9.

Parthenolide inhibits hypoxia-induced EMT pathway. To elucidate mechanism by which PT inhibits hypoxia-induced EMT, we examined the protein levels of EMT-associated markers in CRC cells. First, the level of E-cadherin, a representative epithelial marker, was analyzed by western blotting. Hypoxia treatment decreased the level of E-cadherin, whereas this level was recovered by PT treatment in a dose-dependent manner (Fig. 6, panel 1). In contrast, the expression levels of mesenchymal markers, such as $\beta$-catenin, vimentin, Slug, Snail, and Twist were increased under hypoxic conditions; moreover, PT significantly decreased the expression of all 

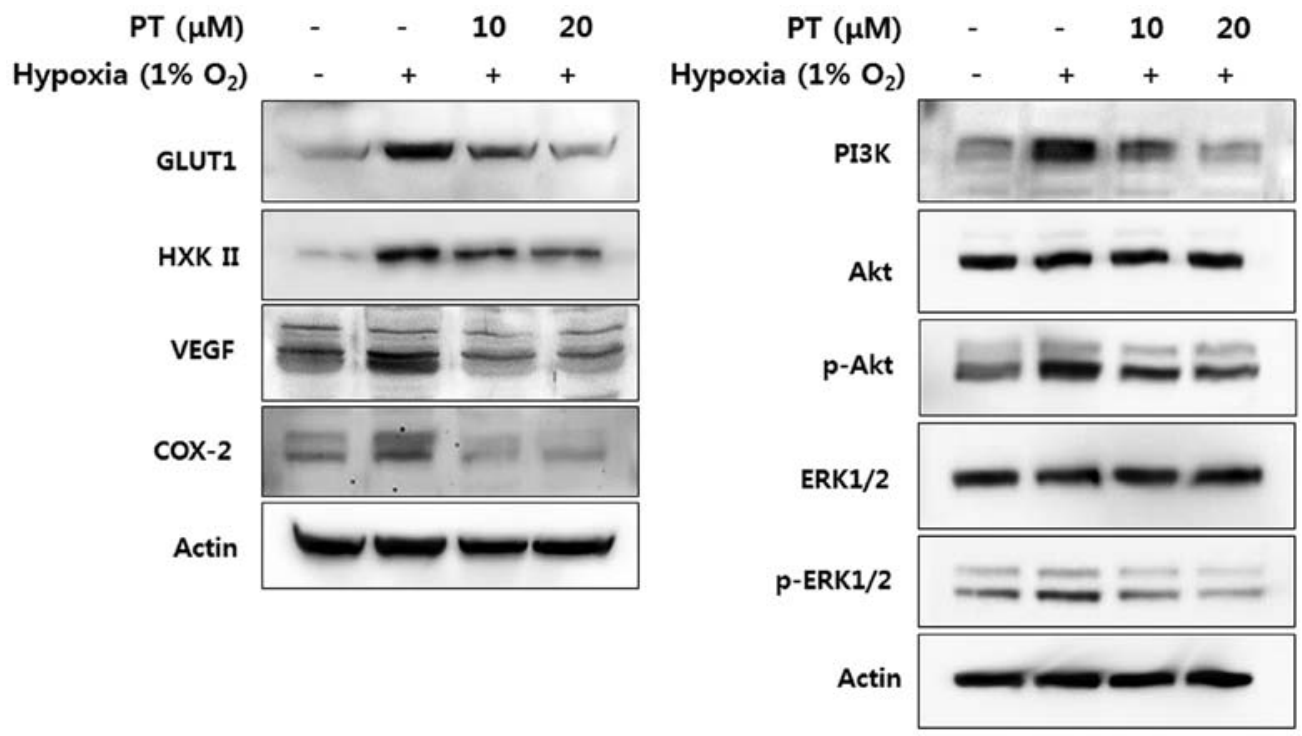

Figure 4. Downregulation of HIF-1 $\alpha$-dependent protein by PT. Total cell lysates of HT-29 cells were prepared after treatment with PT for $24 \mathrm{~h}$ under normoxic or hypoxic conditions and then analyzed by western blotting using GLUT1, HEXII, VEGF, PI3K, p-Akt, p-ERK1/2, COX-2 and actin antibody. Actin was used as a loading control.

A
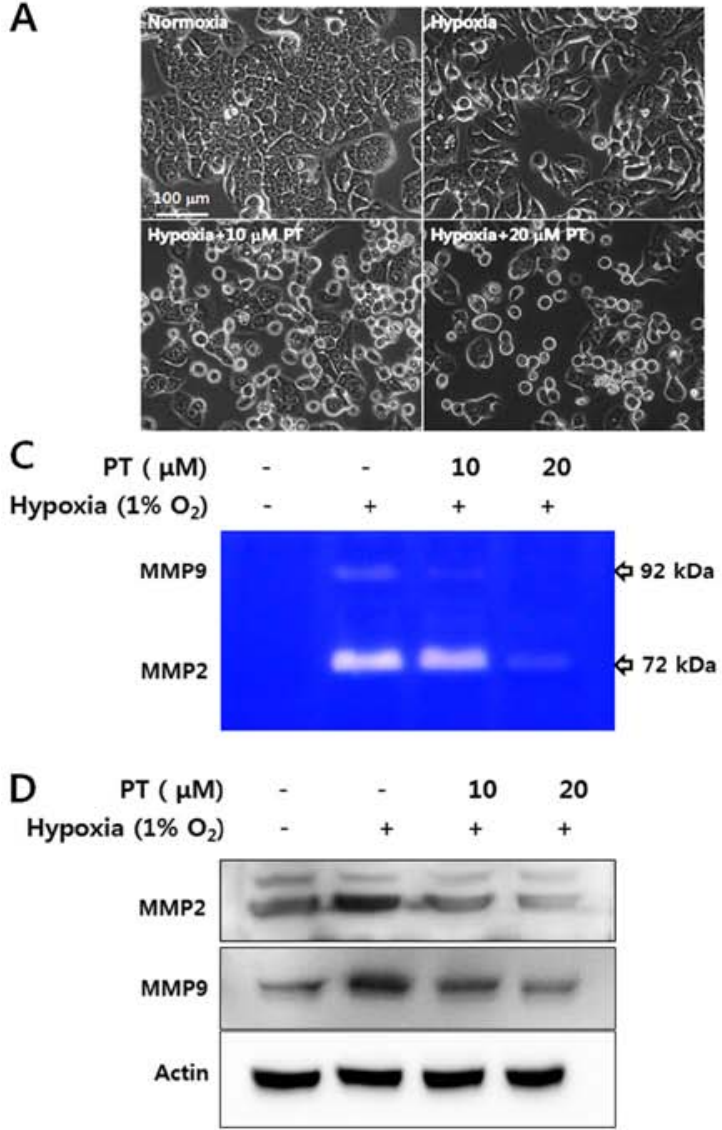

B $\mathrm{Oh}$

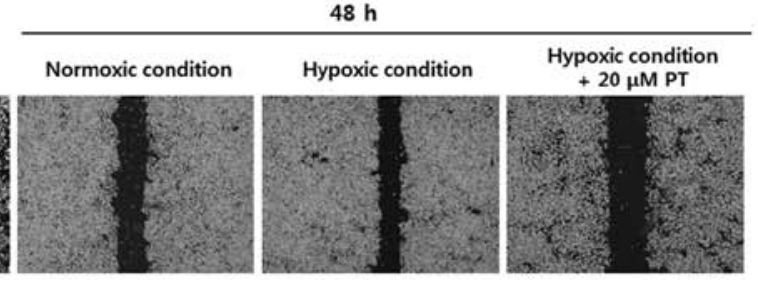

$6 \mathrm{~h}$
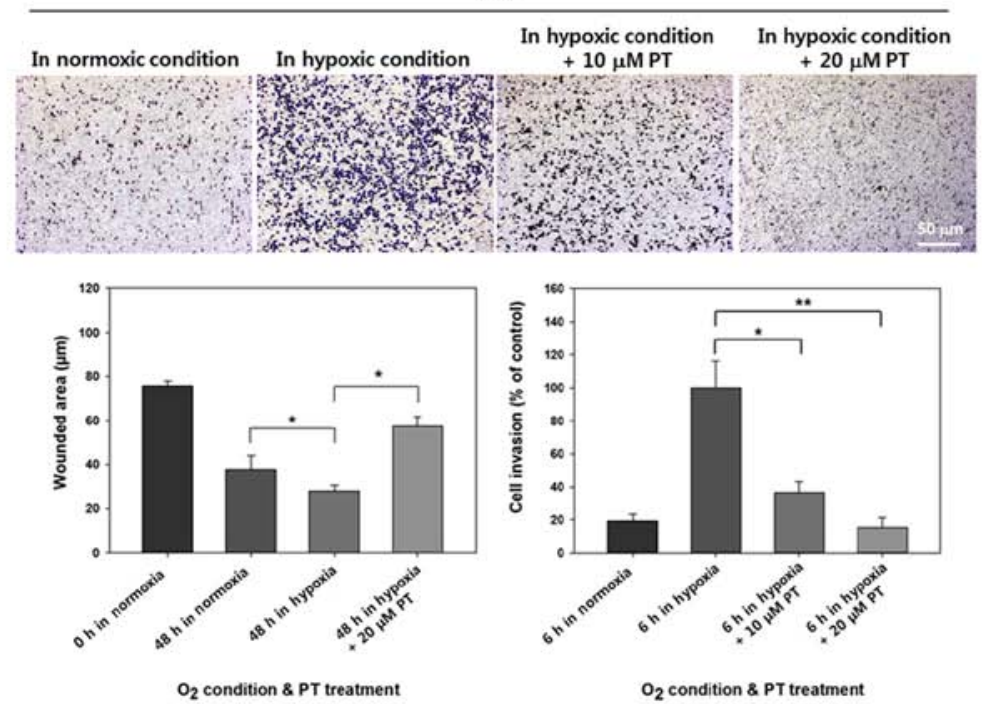

Figure 5. Inhibitory effect of PT on hypoxia-induced EMT in HT-29 cells. (A) Cells were cultured in normal maintenance conditions for 24 h. For hypoxia induction, HT-29 cells were incubated in a hypoxia chamber, either with or without PT at the indicated concentrations, for $24 \mathrm{~h}$. Controls were cultured under normoxic conditions for $24 \mathrm{~h}$. Images were captured using a phase contrast microscope (x10). (B) Cell mobility as detected by a wound healing assay. Cells were incubated under normoxic conditions for $24 \mathrm{~h}$, after which the confluent cell layer was scratched and the cells were exposed to normoxia, hypoxia, or hypoxia plus PT for another $48 \mathrm{~h}$. Scratch closure was monitored for $48 \mathrm{~h}$; photographs taken at 0 and $48 \mathrm{~h}$ post-scratching are shown. The extent of wound closure following treatment with the indicated concentrations of PT was analyzed by measuring the width of the scratch. Cell invasion was assessed using Transwell ${ }^{\circledast}$ cell culture chambers with Matrigel ${ }^{\mathrm{TM}}$-coated membranes. Cells were fixed and stained with crystal violet; images were captured at a magnification of x20. Columns represent the means \pm standard errors (SEs). " $p<0.05$. (C) Conditioned medium samples from cells treated with PT under normoxic or hypoxic conditions were subjected to gelatin zymography. Matrix metalloproteinase activity is visualized as a clear band on the gel. (D) Total lysates were prepared from HT-29 cells after treatment with PT for $24 \mathrm{~h}$ under normoxic or hypoxic conditions. The levels of MMP2, MMP9, and actin were then analyzed by western blotting with the appropriate antibodies. Actin was used as a loading control. 
Table I. The effect of PT on tumor growth in mice bearing the HT-29 tumor.

Tumor volume $\left(\mathrm{mm}^{3}\right)$

\begin{tabular}{lllll}
\cline { 3 - 4 } Group & $\mathrm{n}$ & \multicolumn{1}{c}{7 days } & 15 days & \multicolumn{2}{c}{27 days } \\
\hline Vehicle & 6 & $24.852 \pm 11.581$ & $181.172 \pm 59.177$ & $592.181 \pm 132.425$ \\
PT $(4 \mathrm{mg} / \mathrm{kg})$ & 6 & $23.386 \pm 4.986$ & $118.48 \pm 28.375$ & $330.018 \pm 52.096^{\mathrm{a}}$ \\
\hline
\end{tabular}

Effect of PT on cancer growth in a subcutaneous xenograft tumor model. Data are shown as mean $\pm \mathrm{SD}$ ( $\mathrm{n}=6$ pergroup). ${ }^{\mathrm{a}} \mathrm{p}<0.05$ versus vehicle treated mice.

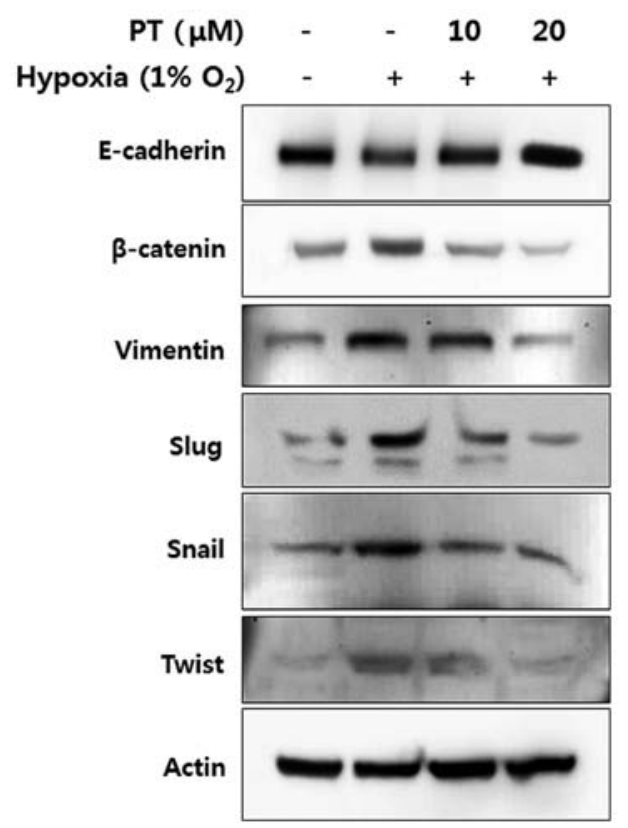

Figure 6. Regulation of hypoxia induced EMT marker by PT. Total cell lysates of HT-29 cells were prepared after treatment with PT for $24 \mathrm{~h}$ under normoxic or hypoxic conditions. The level of E-cadherin, $\beta$-catenin, vimentin, Slug, Snail, Twist and actin were then assessed by western blotting with the appropriate antibodies. Actin was used as a loading control.

mesenchymal markers in a concentration-dependent manner (Fig. 6, panels 2-6). These results indicate that PT treatment inhibits EMT through the upregulation of epithelial markers and the downregulation of mesenchymal markers.

Parthenolide inhibits CRC progression and angiogenesis by affecting the $N F-\kappa B / H I F-1 \alpha / E M T$ signaling pathway. Finally, human $\mathrm{CRC}$ cells were inoculated subcutaneously into athymic nude mice to examine whether PT affects tumorigenicity and cancer progression (Table I and Fig. 7A). At $\sim 1$ week after the start of treatment, the mean tumor volumes of control and PT-treated mice were $24.852 \pm 11.581$ and $23.386 \pm 4.986 \mathrm{~mm}^{3}$, respectively. However, after 4 weeks, the mean tumor volume of PT-treated mice was significantly lower than that of control mice (control mice: $592.181 \pm 132.425 \mathrm{~mm}^{3}$, PT-treated mice: $330.018 \pm 52.096 \mathrm{~mm}^{3}$ ).

To verify the in vitro effects of PT, we examined the expression of CA IX, p65, VWF and vimentin in paraffin-embedded CRC tissue from xenograft models by IHC. First, CA IX is a novel member of the carbonic anhydrase family and the over- expression of CA IX in cancer tissues is strongly regulated by hypoxia, through the HIF-1 mediated transcription (38). Therefore, CA IX is a commonly used hypoxia marker. As shown in Fig. 7B (panel 1), positive staining of CA IX was observed in control tissue. However, treatment with PT revealed a significant reduction in the number of CA IX-positive cells (Fig. 7B, panel 1; p<0.05). Next, cells positively stained for $\mathrm{NF}-\kappa \mathrm{B}$ subunit $\mathrm{p} 65$ were detected in tissues from control group; however, the number of p65 positively stained cells was significantly reduced by $\mathrm{PT}$ treatment, indicating that $\mathrm{PT}$ inhibited NF- $\kappa$ B activation and NF- $\kappa \mathrm{B}$ is implicated in HIF-1 $\alpha$ expression (Fig. 7B, panel 2). Next, VWF, a well-established marker for angiogenesis, was examined. This staining revealed that the blood vessel networks were reduced in the tumor tissue samples from PT-treated mice compared with the networks in control mice, suggesting that PT inhibits hypoxia-induced angiogenesis in vivo (Fig. 7B, panel 3; p<0.05). To further evaluate the effects of PT on EMT, the expression patterns of vimentin were investigated. The number of vimentin-positive cells was significantly decreased in the PT-treated mice compared with the control mice (Fig. 7B, panel 4). Collectively, our IHC results indicate that PT suppresses CRC progression and angiogenesis through the NF- $\kappa \mathrm{B} / \mathrm{HIF}-1 \alpha / \mathrm{EMT}$ pathway, a finding consistent with our in vitro experiments.

\section{Discussion}

In the pro-metastatic environment, hypoxia exerts its effects predominantly by stabilizing HIF-1 $\alpha$. Many clinical and preclinical studies have demonstrated that hypoxia and HIF-1 $\alpha$ are promising anticancer drug targets (4). Therefore, searching pharmacologically active compound from natural sources to suppress cancer progression and metastasis by modulating the hypoxic tumor microenvironment is possible to be an attractive approach to anticancer drug discovery. In the present study, we have identified for the first time that the PT, isolated from medicinal plants, effectively inhibits cancer progression and angiogenesis by inducing HIF-1 $\alpha$ degradation and suppressing hypoxia-induced EMT of CRC cells.

PT exerts a wide spectrum of anticancer activities, ranging from preventing cancer development to enhancing anticancer drug effect in combined therapies. It is well known that the main mechanism of PT in cancer treatment is based on NF- $\kappa \mathrm{B}$ signaling pathway through many published studies. In a previous study, we demonstrated that PT inhibits phosphorylation of $\mathrm{I} \kappa \mathrm{B}-\alpha$ and $\mathrm{NF}-\kappa \mathrm{B}$ activation, resulting in initiation 
A
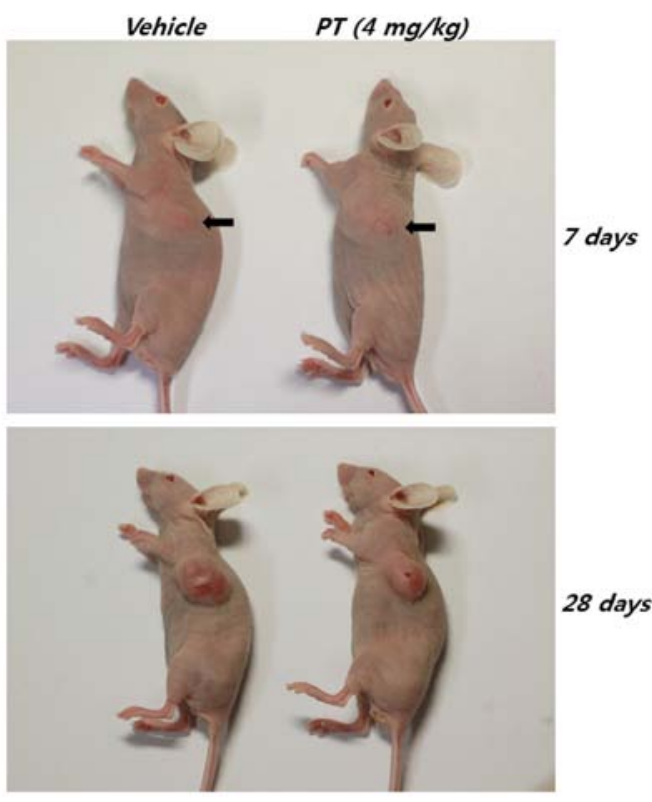

B
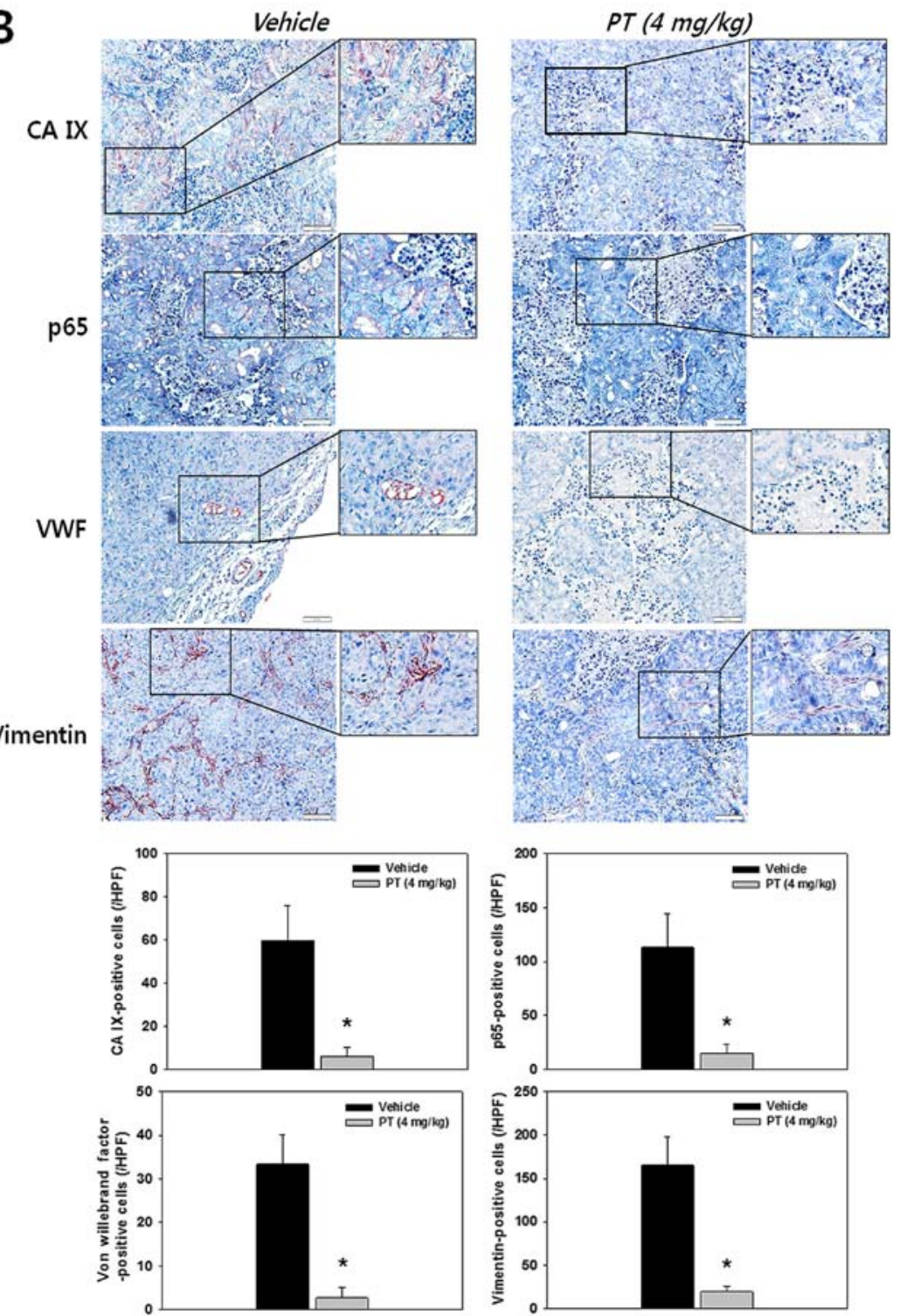

Figure 7. Effects of PT on the HIF-1 $\alpha / \mathrm{NF}-\mathrm{\kappa B}$ signaling pathway in a subcutaneous xenograft tumor model. (A) Representative images of CRC cells xenograft. HT-29 cells were subcutaneously inoculated into nude mice. Mice bearing tumor xenografts were randomly divided into control and PT treatment groups. (B) After sacrifice, tumor sections from the animals were fixed and stained with antibodies against CA IX, p65, VWF and vimentin. Positive staining in samples from control (vehicle-treated) mice is visualized as brown or red spots. The numbers of positive cells in the tumor samples were counted at $\mathrm{x} 40$ magnification. Values represent means \pm standard errors (SEs). ${ }^{* *} \mathrm{p}<0.01 \mathrm{vs}$. the vehicle-treated group. 
of apoptosis, suppression of CRC tumor growth and colitisassociated cancer development $(22,39)$. While the mechanism linking PT to NF- $\kappa \mathrm{B}$ activation has been extensively studied, the effects of PT on HIF-1 $\alpha$ expression and hypoxia-induced EMT has not been previously investigated. In this study, we demonstrate that PT suppresses hypoxia-induced HIF-1 $\alpha$ upregulation and also inhibits EMT by preventing NF- $\kappa$ B activation. These findings support the utility of PT for inhibiting HIF-1 $\alpha$ mediated CRC progression and angiogenesis, thus implying that PT could be used to treat metastatic CRC.

HIF-1 $\alpha$ induction has been demonstrated to be dependent upon $\mathrm{NF}-\kappa \mathrm{B}$ transcriptional activity and this activity is well correlated with HIF-1 $\alpha$ protein level. Moreover, many of the stimuli that induce HIF-1 in normoxic conditions are known to activate a number of other transcription factors such as $\mathrm{NF}-\kappa \mathrm{B}$. In 2003, Jung et al reported that IL-1 $\beta$ upregulates functional $\mathrm{HIF}-1 \alpha$ protein through $\mathrm{NF}-\kappa \mathrm{B}$ signaling pathway, resulted in upregulation of VEGF, a potent angiogenic factor required for tumor growth and metastasis (27). Van Uden et al have presented that $\mathrm{TNF} \alpha$-induced $\mathrm{NF}-\kappa \mathrm{B}$ activation increases the expression level of HIF-1 $\alpha$ and activity, leading to transactivation of target genes under normoxic condition (28). Furthermore, Bonello et al identified that $\mathrm{H}_{2} \mathrm{O}_{2}$ upregulates $\mathrm{HIF}-1 \alpha$ transcription by activating NF- $\kappa \mathrm{B}$, thus linking these important pathways in a common mechanism induced by ROS (40). Conversely, exposure to hypoxia has been shown to activate $\mathrm{NF}-\kappa \mathrm{B}$ signaling. In 2006 , it was reported that hypoxia releases repression of $\mathrm{NF}-\kappa \mathrm{B}$ activity through decreased PHD-dependent hydroxylation of IKK- $\beta$ (41). Koong et al also reported that hypoxia activates $\mathrm{NF}-\kappa \mathrm{B}$ through the phosphorylation of I $\mathrm{B}$ B- $\alpha$ on tyrosine residues (42). Interestingly, several studies have identified a high degree of crosstalk between the $\mathrm{NF}-\kappa \mathrm{B}$ and HIF signaling pathways. Rius et al demonstrated that $\mathrm{NF}-\kappa \mathrm{B}$ activation upregulates HIF-1 $\alpha$ on the transcriptional level and also that basal $N F-\kappa B$ is a prerequisite for constitutive HIF-1 $\alpha$ expression (43). In addition, Belaiba et al reported that the human HIF-1 $\alpha$ promoter includes a NF- $\mathrm{B}$ binding site at a site $-197 /-188$ bp upstream of the transcriptional start site, mutation of which leads to a loss of hypoxic HIF-1 $\alpha$ upregulation (44). Here, we demonstrated that a low oxygen concentration resulted in NF- $\kappa \mathrm{B}$ activation and that the HIF-1 $\alpha$ signaling pathway was suppressed by NF- $\kappa$ B inhibition. Thus, our findings are consistent with the presence of NF- $\kappa$ B-HIF crosstalk.

Inhibition of HRE activation under hypoxic condition can be explained by either a reduction in the expression level of HIF-1 $\alpha$ or the interference of HIF-1 $\alpha$ binding to these elements. Here, we showed that PT inhibited HIF-1 $\alpha$ accumulation under hypoxic condition in a dose-dependent manner. Thus, the expression levels of hypoxia-related elements (including VEGF) are likely decreased due to the reduction in HIF-1 $\alpha$ expression. Since VEGF plays a central role in angiogenesis, antibodies and soluble proteins that block VEGF and VEGF receptors have been investigated for anti-angiogenic therapies. Moreover, a number of studies have indicated that VEGF regulation depends on $\mathrm{NF}-\kappa \mathrm{B}$ activation. Growth factors for angiogenesis are upregulated by $\mathrm{NF}-\kappa \mathrm{B}$ signaling, and $\mathrm{COX} 2$ is known to promote angiogenesis. Moreover, COX2 expression can be induced by $\mathrm{NF}-\kappa \mathrm{B}$ activation $(45,46)$. We previously reported that $\mathrm{PT}$ inhibits angiogenesis by downregulating
VEGF/VEGFRs in CRC cells and HUVECs (47). Similarly, here we showed that PT blocks hypoxia-induced VEGF expression and tube formation in HUVECs. We also showed that PT reduces microvessel formation and tumor growth in vivo. Taken together, these results indicate that $\mathrm{PT}$-mediated inhibition of HIF- $1 \alpha / \mathrm{NF}-\kappa \mathrm{B}$ signaling effectively suppresses hypoxia-mediated angiogenesis in CRC.

We also confirmed protein level of HIF- $1 \alpha$-dependent genes to examine the mechanisms underlying adaptation to hypoxic conditions. Since the oxidative phosphorylation pathway in mitochondria is impaired in hypoxia, several glycolytic enzymes are induced to maintain the supply of ATP required for cell growth and survival (48). Based on these findings, PT-mediated inhibition of GLUT1 and HXK II expression probably prevents adaptation to hypoxia by decreasing the rate of glycolysis. The involvement of the PI3K/Akt pathways in hypoxia-mediated regulation of HIF-1 remains controversial. However, growing evidence has indicated that the PI3K/Akt pathway is affected by hypoxic conditions. Under hypoxic condition, Akt is targeted by PI3K in the inner leaflet of the plasma membrane. Subsequently, Akt is phosphorylated by a phosphoinositide-dependent protein kinase, thereby regulating cancer development and survival $(49,50)$. Moreover, Huang et al reported that decreased nuclear accumulation of HIF-1 $\alpha$ resulted in reduced hypoxia-induced Akt phosphorylation upon treatment with folic acid (51). Numerous studies have also demonstrated that MEK-1/p42/p44 MAPK pathway is involved in hypoxia. Hur et al have also reported that the MAPK inhibitor PD98059 decreases the transactivation ability of HIF-1 $\alpha$ thereby reducing hypoxia-induced transcription of target gene and a hypoxia-responsive reporter gene (52). In the present study, we reported that PT-mediated downregulation of HIF-1 $\alpha$ significantly decreases hypoxiainduced survival and development in vitro, in addition to tumor growth in vivo, by inhibiting the PI3K/Akt and MAPK pathways.

HIF-1 $\alpha$ modulates important steps of the metastatic processes, especially EMT, which is one of the most crucial events resulting in cell migration and invasion in early stage of tumor metastasis (53). Under hypoxic condition, the tumor microenvironment generates major EMT-triggering pathways such as transforming growth factor (TGF)- $\beta$, Notch and $\mathrm{NF}-\kappa \mathrm{B}$ signaling pathways (54). Inflammatory cytokines (including TNF- $\alpha$, IL-1 and IL-6) have been reported to be critical to SNAIL stability and EMT induction through the activation of $\mathrm{NF}-\kappa \mathrm{B}$ signaling (55-57). Furthermore, Cheng et al identified that activation of the HIF-1 $\alpha$ and $\mathrm{NF}-\kappa \mathrm{B}$ loop is mechanically linked with EMT phenotype of pancreatic cancer cells under hypoxic condition showing downregulation of hypoxia-induced EMT by p65 siRNA (58). In the present study, hypoxia-induced EMT was characterized by morphological changes, cell migration and invasion, MMPs enzyme activity, suppression of epithelial marker (E-cadherin) and enhanced expression of mesenchymal markers ( $\beta$-catenin, vimentin, Slug, Snail and Twist). We also showed that suppression of HIF-1 $\alpha$ by $\mathrm{NF}-\kappa \mathrm{B}$ inhibitor led to changes of the cell morphology to epithelial phenotype and decreased hypoxiainduced migration and invasion, and regulation of EMT markers. In addition, we confirmed that PT treatment inhibits $\mathrm{NF}-\kappa \mathrm{B}$ activation, thereby reducing its binding to CA IX 
(a representative hypoxia marker) and vimentin in CRC tissue samples obtained from an in vivo xenograft model. Thus, our data indicate that hypoxia-mediated EMT is intimately connected to $\mathrm{NF}-\kappa \mathrm{B}$ activation. Moreover, our findings implicate $\mathrm{NF}-\kappa \mathrm{B}$ as a principal mediator of HIF-1 $\alpha$-induced EMT in $\mathrm{CRC}$ under hypoxic conditions.

Further studies using metastatic animal model will be needed to determine the precise mechanisms by which PT potently prevents metastasis of CRC. However, these data provide strong evidence that this mechanism involves effective inhibition of the HIF-1 $\alpha$ signaling pathway and hypoxiainduced EMT in CRC.

\section{Acknowledgements}

This study was supported by Basic Science Research Program throughthe NationalResearchFoundation of Korea(NRF)funded by the Ministry of Education (NRF-2014R1A6A3A01057354) and by Fund of Biomedical Research Institute, Chonbuk National University Hospital.

\section{References}

1. Rajaganeshan R, Prasad R, Guillou PJ, Poston G, Scott N and Jayne DG: The role of hypoxia in recurrence following resection of Dukes' B colorectal cancer. Int J Colorectal Dis 23: 1049-1055, 2008.

2. Lunt SJ, Chaudary N and Hill RP: The tumor microenvironment and metastatic disease. Clin Exp Metastasis 26: 19-34, 2009.

3. Guillemin K and Krasnow MA: The hypoxic response: Huffing and HIFing. Cell 89: 9-12, 1997.

4. Semenza GL: Targeting HIF-1 for cancer therapy. Nat Rev Cancer 3: 721-732, 2003.

5. Poon E, Harris AL and Ashcroft M: Targeting the hypoxiainducible factor (HIF) pathway in cancer. Expert Rev Mol Med 11: e26, 2009.

6. Schofield CJ and Ratcliffe PJ: Oxygen sensing by HIF hydroxylases. Nat Rev Mol Cell Biol 5: 343-354, 2004.

7. Semenza GL: Regulation of mammalian $\mathrm{O}_{2}$ homeostasis by hypoxia-inducible factor 1 . Annu Rev Cell Dev Biol 15: 551-578, 1999.

8. Maxwell PH, Wiesener MS, Chang GW, Clifford SC, Vaux EC, Cockman ME, Wykoff CC, Pugh CW, Maher ER and Ratcliffe PJ: The tumour suppressor protein VHL targets hypoxia-inducible factors for oxygen-dependent proteolysis. Nature 399: 271-275, 1999.

9. Semenza GL: HIF-1, O(2), and the 3 PHDs: How animal cells signal hypoxia to the nucleus. Cell 107: 1-3, 2001.

10. Yang J and Weinberg RA: Epithelial-mesenchymal transition: At the crossroads of development and tumor metastasis. Dev Cell 14: 818-829, 2008

11. Hur K, Toiyama Y, Takahashi M,Balaguer F, Nagasaka T, Koike J, Hemmi H, Koi M, Boland CR and Goel A: MicroRNA-200c modulates epithelial-to-mesenchymal transition (EMT) in human colorectal cancer metastasis. Gut 62: 1315-1326, 2013.

12. Turley EA, Veiseh M, Radisky DC and Bissell MJ: Mechanisms of disease: Epithelial-mesenchymal transition - does cellular plasticity fuel neoplastic progression? Nat Clin Pract Oncol 5: 280-290, 2008.

13. Bates RC and Mercurio AM: The epithelial-mesenchymal transition (EMT) and colorectal cancer progression. Cancer Biol Ther 4: 365-370, 2005.

14. Hill RP, Marie-Egyptienne DT and Hedley DW: Cancer stem cells, hypoxia and metastasis. Semin Radiat Oncol 19: 106-111, 2009.

15. Yang $\mathrm{MH}, \mathrm{Wu} \mathrm{MZ}$, Chiou SH, Chen PM, Chang SY, Liu CJ, Teng SC and Wu KJ: Direct regulation of TWIST by HIF-lalpha promotes metastasis. Nat Cell Biol 10: 295-305, 2008.

16. Zhou G, Dada LA, Wu M, Kelly A, Trejo H, Zhou Q, Varga J and Sznajder JI: Hypoxia-induced alveolar epithelial-mesenchymal transition requires mitochondrial ROS and hypoxia-inducible factor 1. Am J Physiol Lung Cell Mol Physiol 297: L1120-L1130, 2009.
17. Bork PM, Schmitz ML, Kuhnt M, Escher C and Heinrich M Sesquiterpene lactone containing Mexican Indian medicinal plants and pure sesquiterpene lactones as potent inhibitors of transcription factor NF-kappaB. FEBS Lett 402: 85-90, 1997.

18. Murphy JJ, Heptinstall S and Mitchell JR: Randomised doubleblind placebo-controlled trial of feverfew in migraine prevention. Lancet 2: 189-192, 1988.

19. Hehner SP, Heinrich M, Bork PM, Vogt M, Ratter F, Lehmann V, Schulze-Osthoff K, Dröge W and Schmitz ML: Sesquiterpene lactones specifically inhibit activation of NF-kappa B by preventing the degradation of I kappa B-alpha and I kappa B-beta. J Biol Chem 273: 1288-1297, 1998.

20. Oka D, Nishimura K, Shiba M, Nakai Y, Arai Y, Nakayama M, Takayama H, Inoue H, Okuyama $A$ and Nonomura N: Sesquiterpene lactone parthenolide suppresses tumor growth in a xenograft model of renal cell carcinoma by inhibiting the activation of NF-kappaB. Int J Cancer 120: 2576-2581, 2007.

21. Kishida Y, Yoshikawa $\mathrm{H}$ and Myoui A: Parthenolide, a natural inhibitor of nuclear factor-kappaB, inhibits lung colonization of murine osteosarcoma cells. Clin Cancer Res 13: 59-67, 2001

22. Kim SL, Liu YC, Seo SY, Kim SH, Kim IH, Lee SO, Lee ST, Kim DG and Kim SW: Parthenolide induces apoptosis in colitisassociated colon cancer, inhibiting NF- $\kappa \mathrm{B}$ signaling. Oncol Lett 9: 2135-2142, 2015.

23. Luo JL, Kamata $\mathrm{H}$ and Karin M: IKK/NF-kappaB signaling: Balancing life and death - a new approach to cancer therapy. J Clin Invest 115: 2625-2632, 2005.

24. Hayden MS and Ghosh S: Signaling to NF-kappaB. Genes Dev 18: 2195-2224, 2004

25. Royds JA, Dower SK, Qwarnstrom EE and Lewis CE: Response of tumour cells to hypoxia: Role of p53 and NFkB. Mol Pathol 51: 55-61, 1998.

26. Kwon HC, Kim SH, Oh SY, Lee S, Kwon KA, Lee JH, Choi HJ, Park KJ, Lee HS, Roh MS, et al: Clinicopathological significance of nuclear factor-kappa B, HIF-1 alpha, and vascular endothelial growth factor expression in stage III colorectal cancer. Cancer Sci 101: 1557-1561, 2010.

27. Jung YJ, Isaacs JS, Lee $S$, Trepel $J$ and Neckers L: IL-1betamediated up-regulation of HIF-1alpha via an NFkappaB/COX-2 pathway identifies HIF-1 as a critical link between inflammation and oncogenesis. FASEB J 17: 2115-2117, 2003.

28. van Uden P, Kenneth NS and Rocha S: Regulation of hypoxiainducible factor-1alpha by NF-kappaB. Biochem J 412: 477-484, 2008.

29. Nam SY, Ko YS, Jung J, Yoon J, Kim YH, Choi YJ, Park JW, Chang MS, Kim WH and Lee BL: A hypoxia-dependent upregulation of hypoxia-inducible factor- 1 by nuclear factor- $\kappa \mathrm{B}$ promotes gastric tumour growth and angiogenesis. Br J Cancer 104: 166-174, 2011

30. Wu Y and Zhou BP: TNF-alpha/NF-kappaB/Snail pathway in cancer cell migration and invasion. Br J Cancer 102: 639-644, 2010.

31. Yu L, Mu Y, Sa N, Wang $\mathrm{H}$ and $\mathrm{Xu} \mathrm{W}$ : Tumor necrosis factor $\alpha$ induces epithelial-mesenchymal transition and promotes metastasis via NF- $\kappa \mathrm{B}$ signaling pathway-mediated TWIST expression in hypopharyngeal cancer. Oncol Rep 31: 321-327, 2014.

32. Cheng ZX, Sun B, Wang SJ, Gao Y, Zhang YM, Zhou HX, Jia G, Wang YW, Kong R, Pan SH, et al: Nuclear factor- $\kappa \mathrm{B}$-dependent epithelial to mesenchymal transition induced by HIF-1 $\alpha$ activation in pancreatic cancer cells under hypoxic conditions. PLoS One 6: e23752, 2011.

33. Forsythe JA, Jiang BH, Iyer NV, Agani F, Leung SW, Koos RD and Semenza GL: Activation of vascular endothelial growth factor gene transcription by hypoxia-inducible factor 1 . Mol Cell Biol 16: 4604-4613, 1996.

34. Tozer GM, Kanthou C and Baguley BC: Disrupting tumour blood vessels. Nat Rev Cancer 5: 423-435, 2005.

35. Xia X, Lemieux ME, Li W, Carroll JS, Brown M, Liu XS and Kung AL: Integrative analysis of HIF binding and transactivation reveals its role in maintaining histone methylation homeostasis. Proc Natl Acad Sci USA 106: 4260-4265, 2009.

36. Thiery JP and Sleeman JP: Complex networks orchestrate epithelial-mesenchymal transitions. Nat Rev Mol Cell Biol 7: 131-142, 2006.

37. Zhu S, Zhou Y, Wang L, Zhang J, Wu H, Xiong J, Zhang J, Tian Y, Wang C and Wu H: Transcriptional upregulation of MT2-MMP in response to hypoxia is promoted by HIF-1 $\alpha$ in cancer cells. Mol Carcinog 50: 770-780, 2011 
38. Ambrosio MR, Di Serio C, Danza G, Rocca BJ, Ginori A Prudovsky I, Marchionni N, Del Vecchio MT and Tarantini F: Carbonic anhydrase IX is a marker of hypoxia and correlates with higher Gleason scores and ISUP grading in prostate cancer. Diagn Pathol 11: 45, 2016.

39. Kim SL, Trang KT, Kim SH, Kim IH, Lee SO, Lee ST, Kim DG and Kim SW: Parthenolide suppresses tumor growth in a xenograft model of colorectal cancer cells by inducing mitochondrial dysfunction and apoptosis. Int J Oncol 41: 1547-1553, 2012.

40. Bonello S, Zähringer C, BelAiba RS, Djordjevic T, Hess J, Michiels C, Kietzmann T and Görlach A: Reactive oxygen species activate the HIF-1alpha promoter via a functional NFkappaB site. Arterioscler Thromb Vasc Biol 27: 755-761, 2007.

41. Cummins EP, Berra E, Comerford KM, Ginouves A, Fitzgerald KT, Seeballuck F, Godson C, Nielsen JE, Moynagh P, Pouyssegur J, et al: Prolyl hydroxylase-1 negatively regulates IkappaB kinase-beta, giving insight into hypoxia-induced NFkappaB activity. Proc Natl Acad Sci USA 103: 18154-18159, 2006.

42. Koong AC, Chen EY and Giaccia AJ: Hypoxia causes the activation of nuclear factor kappa B through the phosphorylation of I kappa B alpha on tyrosine residues. Cancer Res 54: 1425-1430, 1994.

43. Rius J, Guma M, Schachtrup C, Akassoglou K, Zinkernagel AS Nizet V, Johnson RS, Haddad GG and Karin M: NF-kappaB links innate immunity to the hypoxic response through transcriptional regulation of HIF-1alpha. Nature 453: 807-811, 2008.

44. Belaiba RS, Bonello S, Zähringer C, Schmidt S, Hess J, Kietzmann $T$ and Görlach A: Hypoxia up-regulates hypoxia-inducible factor-1alpha transcription by involving phosphatidylinositol 3-kinase and nuclear factor kappaB in pulmonary artery smooth muscle cells. Mol Biol Cell 18: 46914697, 2007.

45. Huang S, DeGuzman A, Bucana CD and Fidler IJ: Nuclear factor-kappaB activity correlates with growth, angiogenesis, and metastasis of human melanoma cells in nude mice. Clin Cancer Res 6: 2573-2581, 2000

46. Tsujii M, Kawano S, Tsuji S, Sawaoka H, Hori M and DuBois RN: Cyclooxygenase regulates angiogenesis induced by colon cancer cells. Cell 93: 705-716, 1998

47. Kim SL, Lee ST, Trang KT, Kim SH, Kim IH, Lee SO, Kim DG and Kim SW: Parthenolide exerts inhibitory effects on angiogenesis through the downregulation of VEGF/VEGFRs in colorectal cancer. Int J Mol Med 33: 1261-1267, 2014.

48. Semenza GL, Roth PH, Fang HM and Wang GL: Transcriptional regulation of genes encoding glycolytic enzymes by hypoxiainducible factor 1. J Biol Chem 269: 23757-23763, 1994.
49. Joshi S, Singh AR and Durden DL: MDM2 regulates hypoxic hypoxia-inducible factor $1 \alpha$ stability in an E3 ligase, proteasome, and PTEN-phosphatidylinositol 3-kinase-AKT-dependent manner. J Biol Chem 289: 22785-22797, 2014.

50. Mottet D, Dumont V, Deccache Y, Demazy C, Ninane N, Raes M and Michiels C: Regulation of hypoxia-inducible factor-1alpha protein level during hypoxic conditions by the phosphatidylinositol 3-kinase/Akt/glycogen synthase kinase 3beta pathway in HepG2 cells. J Biol Chem 278: 31277-31285, 2003.

51. Huang X, He Z, Jiang X, Hou M, Tang Z, Zhen X, Liang Y and Ma J: Folic acid represses hypoxia-induced inflammation in THP-1 cells through inhibition of the PI3K/Akt/HIF-1 $\alpha$ pathway. PLoS One 11: e0151553, 2016.

52. Hur E, Chang KY, Lee E, Lee SK and Park H: Mitogen-activated protein kinase kinase inhibitor PD98059 blocks the transactivation but not the stabilization or DNA binding ability of hypoxia-inducible factor-1alpha. Mol Pharmacol 59: 1216-1224, 2001.

53. Cannito S, Novo E, Compagnone A, Valfrè di Bonzo L, Busletta C, Zamara E, Paternostro C, Povero D, Bandino A, Bozzo F, et al: Redox mechanisms switch on hypoxia-dependent epithelial-mesenchymal transition in cancer cells. Carcinogenesis 29: 2267-2278, 2008.

54. Jiang J, Tang YL and Liang XH: EMT: A new vision of hypoxia promoting cancer progression. Cancer Biol Ther 11: 714-723, 2011.

55. Chuang MJ, Sun KH, Tang SJ, Deng MW, Wu YH, Sung JS, Cha TL and Sun GH: Tumor-derived tumor necrosis factor-alpha promotes progression and epithelial-mesenchymal transition in renal cell carcinoma cells. Cancer Sci 99: 905-913, 2008.

56. Sullivan NJ, Sasser AK, Axel AE, Vesuna F, Raman V, Ramirez N, Oberyszyn TM and Hall BM: Interleukin-6 induces an epithelial-mesenchymal transition phenotype in human breast cancer cells. Oncogene 28: 2940-2947, 2009.

57. St John MA, Dohadwala M, Luo J, Wang G, Lee G, Shih H, Heinrich E, Krysan K, Walser T, Hazra S, et al: Proinflammatory mediators upregulate snail in head and neck squamous cell carcinoma. Clin Cancer Res 15: 6018-27, 2009.

58. Cheng ZX, Wang DW, Liu T, Liu WX, Xia WB, Xu J, Zhang YH, Qu YK, Guo LQ, Ding L, et al: Effects of the HIF-1 $\alpha$ and NF-kB loop on epithelial-mesenchymal transition and chemoresistance induced by hypoxia in pancreatic cancer cells. Oncol Rep 31: 1891-1898, 2014 